\title{
Identification of Cyt2Ba from a New Strain of Bacillus thuringiensis and Its Toxicity in Bradysia difformis
}

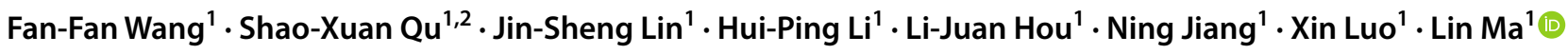

Received: 20 November 2019 / Accepted: 7 May 2020 / Published online: 3 July 2020

(c) The Author(s) 2020

\begin{abstract}
Bradysia difformis is one of the most damaging pests in mushroom production in China. In this study, eight Bacillus thuringiensis strains were analyzed for insecticidal activity in B. difformis. The strain JW-1 showed the highest insecticidal activity against $B$. difformis larvae, but did not inhibit the mycelial growth of Pleurotus ostreatus and P. geesteranus. The 16S rRNA gene (1397 bp) and cyt2 gene (792 bp) were obtained from strain JW-1. The phylogenetic tree based on 16S rRNA gene and Cyt 2 toxin showed that strain JW-1 was a member of B. thuringiensis and Cyt 2 toxin belonged to Cyt2Ba toxin cluster. The Cyt2Ba toxin from strain JW-1 was overexpressed in E. coli as a fusion protein and the fusion protein $(70 \mathrm{kDa})$ was purified by Ni-IDA affinity chromatography. The purified Cyt2Ba fusion protein was toxic to $B$. difformis larvae $\left(\mathrm{LC}_{50}\right.$ was $2.25 \mathrm{ng} /$ $\mathrm{mL}$ ). The identification of Cyt2Ba from strain JW-1 and confirmation of the insecticidal activity of Cyt2Ba in B. difformis provided a new means of biological control of the important pest in mushroom production.
\end{abstract}

\section{Introduction}

Bradysia difformis, belonging to the Sciaridae family, is one of the most destructive greenhouse pests, primarily affecting edible mushroom cultivation [1]. Adult female flies lay eggs on the surface of the growing mushrooms, and the larvae mostly eat hyphae and fruiting bodies, directly damaging the mushroom produce [2]. Adult flies also spread fungal spores and mites when flying over mushrooms, which indirectly leads to lower yields [3]. Bradysia spp. can be controlled by traditional chemical agents because of their simplicity, effectiveness, and speed [4]. However, resistance and residual insecticide pose major threats to the mushroom industry [5, 6]. The current trend is to shift to integrated and eco-friendly pest-management, involving microorganisms with insecticidal activity, such as Bacillus thuringiensis [7, 8].

Bacillus thuringiensis (Bt) is a gram-positive, endosporeforming, ubiquitous soil bacterium that produces parasporal crystals during the sporulation phase of its growth cycle

Lin Ma

malin1590@sina.com

1 Vegetable Research Institute, Jiangsu Key Laboratory for Horticultural Crop Genetic Improvement, Jiangsu Academy of Agricultural Sciences, Nanjing 210014, China

2 Institute of Life Science, Jiangsu University, Zhenjiang 210023, China
$[9,10]$. These parasporal crystals contain different types of proteins with insecticidal activity, the insecticidal crystal proteins (ICP) [11]. Different ICPs possess highly specific insecticidal activities against numerous target insects, such as Lepidoptera, Diptera, Coleoptera, Hymenoptera, Homoptera, as well as some invertebrates such as Nemathelminthes and Platyhelminthes [12-14]. The insecticidal specificity of B. thuringiensis strains is determined by cry and cyt genes. These genes code for insecticidal crystal (Cry) protein of 65-145 kDa and cytolytic (Cyt) proteins of 25-28 kDa, which exert cytolytic activity against a broad spectrum of eukaryotic cells $[15,16]$. Approximately 825 cry and cyt genes have been discovered (https://www.lifesci.sussex.ac. uk/home/Neil_Crickmore/Bt/).

Compared to Cry toxins, Cyt toxins show insecticidal activity only in Diptera and may suppress the resistance to Cry toxins [17-19]. Cyt toxins are composed of a single $\alpha-\beta$ domain and are classified into Cyt1, Cyt2, and Cyt3 [20, 21]. The size of Cyt2 (about $29 \mathrm{kDa}$ ) is slightly larger than that of Cyt 1 (about $27 \mathrm{kDa}$ ) and contains an additional 15-residue sequence at the C-terminus [22]. Furthermore, Cyt2 toxin is readily expressed and forms cytoplasmic inclusions in bacteria without the need for a "helper" protein-like Cyt1 [23]. Cyt2 toxins act synergistically with Cry4Aa, Cry4Ba, and Cry11Aa [24, 25]. Proteolytically activated Cyt2Ba exhibits higher toxicity against Anopheles, Culex, and Aedes larvae than Cyt1 Ab from B. thuringiensis subsp. medellin [26]. 
JW-1 is a Bt strain with insecticidal activity against $B$. difformis and contains a cyt2 gene. At present, there are no sufficient studies on Cyt2Ba toxin against $B$. difformis on edible mushrooms. In this study, the cyt 2 gene from JW-1 was expressed in Escherichia coli and purified to determine its insecticidal activity on $B$. difformis under laboratory conditions.

\section{Materials and Methods}

\section{Bradysia difformis}

Bradysia difformis eggs were initially collected from a mushroom greenhouse in Jiangsu Province, China, in 2014. The larvae were fed mushroom mycelia and placed in plastic boxes in the laboratory. Adult flies oviposited on the surface of mycelium. The third instar larvae were used in insecticidal activity assays. All experiments were conducted at $25 \pm 1{ }^{\circ} \mathrm{C}$ and relative humidity at $65 \pm 5 \%$.

\section{Bacterial Strains, Plasmid, and Culture Conditions}

Eight Bt strains were isolated from the soil collected from the Purple Mountain of Nanjing City, Jiangsu Province, China (GPS locality: N118 86' 16.94"; E32 $07^{\circ}$ 44.11"). The strain B. thuringiensis var. israelensis (Bti) was isolated from the Bti wettable powder from Wuhan Kernel Bio-tech Co., Ltd. (Wuhan, China). For assessment of insecticidal activity, Bt strains were grown in beef extract-peptoneglucose broth (BPG medium; beef extract: $3 \mathrm{~g} / \mathrm{L}$, peptone: $5 \mathrm{~g} / \mathrm{L}$, and glucose: $10 \mathrm{~g} / \mathrm{L}$ ) for $72 \mathrm{~h}$ at $30{ }^{\circ} \mathrm{C}, 220 \mathrm{rpm}$. $E$. coli were cultured in Luria-Bertani (LB) broth at $37{ }^{\circ} \mathrm{C}$, $220 \mathrm{rpm}$. The plasmids and bacterial strains used in this study are listed in Table 1.

\section{Insecticidal Activity Assay}

Insecticidal toxicity of the eight $\mathrm{Bt}$ strains and their Cyt2 toxins were analyzed in third instar larvae of $B$. difformis by larval feeding assay [27]. Single colonies of the eight $\mathrm{Bt}$ strains were individually inoculated into $5 \mathrm{~mL}$ of BPG broth overnight at $30{ }^{\circ} \mathrm{C}, 200 \mathrm{rpm}$, and $0.5 \mathrm{~mL}$ of this culture solution was then transferred to $50 \mathrm{~mL}$ of BPG broth and inoculated again for $72 \mathrm{~h}$ using the same culture conditions. The liquid cultures of the strains were normalized to 0.7 at $\mathrm{OD}_{600}$ using the BPG broth. Three fresh pieces (diameter of $1 \mathrm{~cm}$ ) of fruiting A. polytricha, soaked in Bt strain normalized broth $(2 \mathrm{~mL})$ or Cyt 2 toxin diluent $(2 \mathrm{~mL})$ were placed on a $9-\mathrm{cm}$ plate. One piece of the filter paper (Sangon Biotech, Shanghai, China), wetted by $0.8 \mathrm{~mL}$ of same liquid as used for A. polytricha, was laid on the bottom of the plate. Thirty larvae were transferred into every plate and kept at $25 \pm 1{ }^{\circ} \mathrm{C}$ and $65 \pm 5 \%$ relative humidity for $72 \mathrm{~h}$. All assays were performed in triplicates. BPG broth was used as a control, and the Bti strain was used as a positive control. Mortality and correct mortality were calculated [27], and statistical analysis was performed [28].

\section{Antifungal Activity Assay}

The effects of Bt strains that showed the highest insecticidal activity against $B$. difformis on the hyphal growth of Pleurotus ostreatus and $P$. geesteranus were determined by the confrontation culture method [29]. A PDA disc (5 $\mathrm{mm}$ in diameter) containing the mycelia above was placed onto the center of each 9-cm plate. A 5- $\mu \mathrm{L}$ aliquot of Bt strain fermentation broth was immediately spotted onto the same plate equidistant from the edge of the fungal disc. Bti fermentation broth was used as a control. Three replicates of plate bioassays

Table 1 Bacterial strains and plasmids

\begin{tabular}{|c|c|c|}
\hline Strain or plasmid & Relevant characteristics & Source \\
\hline \multicolumn{3}{|l|}{ Bt strains } \\
\hline $\begin{array}{l}\text { JW-1, 51-4, 68-6, 69-1, } \\
\quad 69-3,88-1,99-3,214-4\end{array}$ & Wild-type strains with insecticidal activity & This study \\
\hline Bti & Purified from Bacillus thuringiensis subsp. israelensis wettable powder & Wuhan Kernel \\
\hline Edible fungus strains & Pleurotus ostreatus, Pleurotus geesteranus, Auricularia polytricha & This study \\
\hline \multicolumn{3}{|l|}{ Escherichia coli } \\
\hline TOP10 & $\begin{array}{l}\text { F- } m c r A \Delta(m r r \text {-hsd RMS- } m c r \mathrm{BC}) \varphi 80 \text { lacZ } \Delta \mathrm{M} 15 \Delta \mathrm{lacX} 74 \text { recA1 ara } \Delta 139 \Delta(\text { ara-leu }) 7697 \text { galU } \\
\text { galK rps (Strr) endA1 nupG }\end{array}$ & Zoonbio \\
\hline Arctic & $\mathrm{F}-$ omp $T h s d S(\mathrm{rB}-\mathrm{mB}-) d c m+$ Tetr gal $\lambda(\mathrm{DE} 3)$ end A Hte [cpn10 cpn60 Gentr] [argU proL Strr] & \\
\hline \multicolumn{3}{|l|}{ Plasmids } \\
\hline PMAL-c5x & Expression vector for $c y t 2, \mathrm{MBP}, \mathrm{Ap}^{\mathrm{r}}$ & Zoonbio \\
\hline pCYT-2 & pMAL-c5x carrying 792-bp PCR product of the $c y t 2, \mathrm{Ap}^{\mathrm{r}}$ & This study \\
\hline
\end{tabular}


were performed independently. The inoculated plates were incubated in the dark for one week at $25 \pm 1{ }^{\circ} \mathrm{C}$.

\section{S rRNA Gene and cyt2 Gene Analysis}

The single colony of Bt strain JW-1 was incubated in $5 \mathrm{~mL}$ of LB broth overnight at $30^{\circ} \mathrm{C}, 200 \mathrm{rpm}$. The bacterial cells were resuspended in $600 \mu \mathrm{L}$ sorbitol buffer $(1.2 \mathrm{M}$ with $0.1 \mathrm{M}$ phosphate-buffered saline (PBS) and $5 \mu \mathrm{L}$ lysozyme $(0.05 \mathrm{~g} / \mathrm{mL})$ and kept at $30^{\circ} \mathrm{C}$ overnight in the water bath. Total DNA of JW-1 was extracted using the Bacterial Genome Extraction Kit (TsingKe, Nanjing, China).

The 16S rRNA gene of the strain JW-1was amplified using the universal primers 27F and 1492R [30]. According to the complete cyt2Ba gene of strain HD-567 (GenBank accession no. GQ919039.1), primers JW-1-cyt2F/R (JW1-cyt2F: 5'-CCATATGGATGCACCTTAATAATTTGAA3'; JW-1-cyt2R: 5'-CCCGCTTGTTACGATTTTATTGGA TTAACAT- $3^{\prime}$ ) were designed using the Primer Premier 5 software [31] and were used to amplify the full cyt2 gene of JW-1. Amplification was carried out with I-5 ${ }^{\mathrm{TM}} \mathrm{Hi}-\mathrm{Fi}$ DNA Polymerase (TsingKe Company). The cycling program for PCR of the 16S rRNA gene included 35 cycles of $98{ }^{\circ} \mathrm{C}$ for $10 \mathrm{~s}, 50^{\circ} \mathrm{C}$ for $10 \mathrm{~s}$, and $72{ }^{\circ} \mathrm{C}$ for $15 \mathrm{~s}$ and the cycling program for PCR of the cyt 2 gene included 35 cycles of $98^{\circ} \mathrm{C}$ for $10 \mathrm{~s}, 50{ }^{\circ} \mathrm{C}$ for $10 \mathrm{~s}$, and $72{ }^{\circ} \mathrm{C}$ for $10 \mathrm{~s}$. Sequencing reads of $16 \mathrm{~S}$ rRNA and cyt 2 were assembled by DNASTAR Lasergene package version 7.1.0, and the DNA nucleotide sequences of $16 \mathrm{~S}$ rRNA and cyt 2 were deposited in the GenBank database under the Accession Numbers (MN539648.1 and MN539642.1). Phylogenetic trees were constructed based on 16S rRNA gene and Cyt2 toxin sequences of JW-1 using MEGA 6.0 software [32]. The evolutionary history was inferred by using the Maximum Likelihood method and a bootstrap analysis of 1000 replications was performed [33].

\section{Expression Vector Construction}

To investigate the insecticidal activity of the Cyt 2 toxin from JW-1, the Cyt 2 protein was expressed in E. coli, by inserting the blunt-end PCR product (complete sequence of the $792 \mathrm{bp}$ $c y t 2$ gene) into the multiple cloning site of pMAL-c5X, following manufacturer's instructions, to produce the plasmid pCYT-2. pCYT-2 was then transformed into E. coli TOP10 competent cells, and the transformants were identified on LB agar containing ampicillin $(100 \mu \mathrm{g} / \mathrm{mL})$. The $c y t 2$ gene was amplified from the $E$. coli colonies with the primers JW1 -cyt2F/R to confirm the presence of the plasmid.

The expression of Cyt 2 in E. coli with pCYT-2 was induced by addition of $0.5 \mathrm{mM}$ of isopropyl- $\beta$-D-1thiogalactopyranoside (IPTG) to the culture and incubation at $20^{\circ} \mathrm{C}$ overnight, as described previously [34]. Following this, $1 \mathrm{~mL}$ of the induced bacterial solution was centrifuged at 10,000 rpm for $2 \mathrm{~min}$, and the cell pellets were suspended in $100 \mu \mathrm{L}$ of $\times 1$ loading buffer (SDS: $20 \mathrm{mg} / \mathrm{mL}$, bromophenol blue: $0.1 \mathrm{mg} / \mathrm{mL}, 1 \mathrm{M}$ Tris- $\mathrm{HCl}$, pH6.8: $25 \mu \mathrm{L} / \mathrm{mL}$, glycerinum: $0.1 \mathrm{~mL} / \mathrm{mL}$, and adding 5 $\mu \mathrm{L} / \mathrm{mL}$ of $\beta$-mercaptoethanol before using). The solution was centrifuged at $4000 \mathrm{rpm}$ for $10 \mathrm{~min}$, and the cell pellets were resuspended in PBS. After disrupting the suspension by ultrasonication, the proteins in the supernatant and the precipitate were analyzed by sodium dodecyl sulfate-polyacrylamide gel electrophoresis (SDS-PAGE) [35].

\section{Purification and Western Blot Analysis of Cyt2 Fusion Protein}

The supernatant from the Cyt2 preparation from above was loaded onto a Ni-IDA Sepharose CL-6B affinity chromatography column pre-equilibrated with Ni-IDA binding buffer at $0.5 \mathrm{~mL} / \mathrm{min}$. The column was washed by Ni-IDA binding buffer at $0.5 \mathrm{~mL} / \mathrm{min}$ and Ni-IDA washing buffer (20 mM Tris- $\mathrm{HCl}, \mathrm{pH} 8.0$, containing $20 \mathrm{mM}$ imidazole and $150 \mathrm{mM} \mathrm{NaCl}$ ) at $1 \mathrm{~mL} / \mathrm{min}$ until the $\mathrm{OD}_{280}$ value of the effluent reached the baseline. The column was then eluted with Ni-IDA elution buffer ( $20 \mathrm{mM}$ Tris-HCl, $\mathrm{pH} 8.0$, containing $250 \mathrm{mM}$ imidazole and $150 \mathrm{mM} \mathrm{NaCl}$ ) at $1 \mathrm{~mL} / \mathrm{min}$ to obtain the target protein. The collected protein solution was dialyzed overnight against tris-buffered saline (TBS) (20 mM Tris-HCl, $150 \mathrm{mM} \mathrm{NaCl}, \mathrm{pH}$ 8.0). The dialysate was analyzed by $12 \%$ SDS-PAGE.

Western blot analysis was performed as previously described [36]. The purified recombinant Cyt2 toxin was separated by SDS-PAGE and transferred to polyvinylidene difluoride (PVDF) membrane, and then the PVDF membrane was washed four times by PBS-Tween 20 (PBST, 0.1\% Tween 20) buffer and incubated with His-tag primary antibody (Zoonbio Biotechnology, Nanjing, China) diluted by $5 \%$ skim milk blocking buffer $(1: 1000)$ at $4{ }^{\circ} \mathrm{C}$ overnight. After washing three times with PBST buffer, the membrane was incubated with goat anti-mouse IgG-conjugated alkaline phosphatase (Zoonbio Biotechnology, Nanjing, China) prepared in 5\% skim milk blocking buffer $(1: 5000)$ at $37^{\circ} \mathrm{C}$ for $1 \mathrm{~h}$. The membrane was then washed four times with PBST buffer. Images were developed by enhanced chemiluminescence (ECL). Protein concentrations were determined by Bradford protein assay (Bio-Rad Laboratories, Hercules, CA) on samples solubilized as previously described.

\section{Results}

\section{Determination of Toxicity and Inhibitory Activity}

Eight laboratory Bt strains that produced parasporal crystals were used to determine the virulence on the larvae 


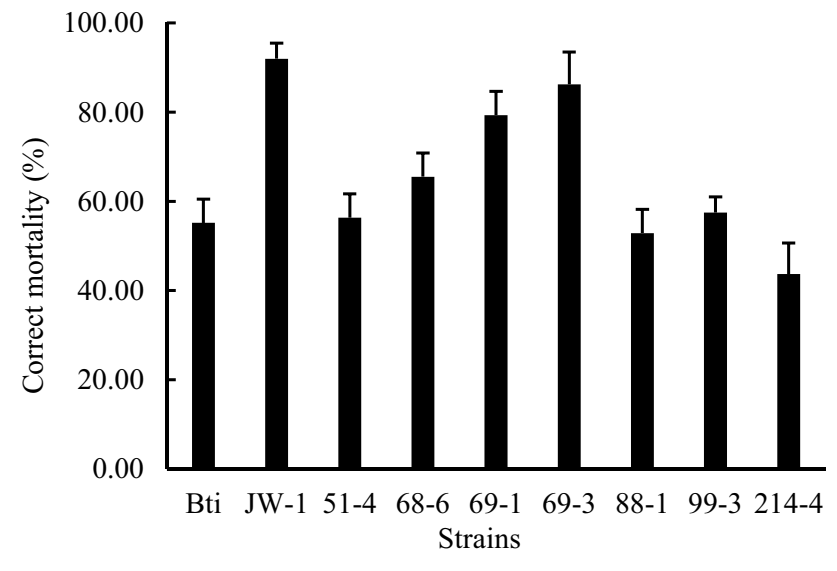

Fig. 1 The toxicity of Bt strains in B. difformis larvae. Insecticidal toxicity of the eight Bt strains and their Cyt2 toxins were analyzed in third instar larvae of $B$. difformis by larval feeding assay. Bti strain was used as a positive control

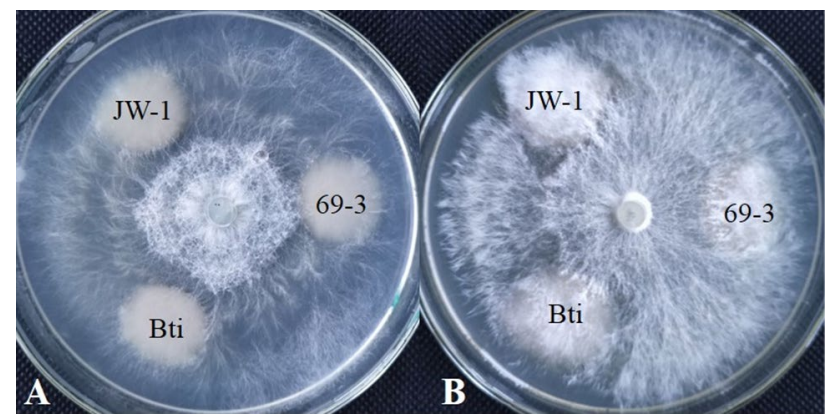

Fig. 2 Antifungal activities of Bt strains against hyphae of $P$. ostreatus (a) and $P$. geesteranus (b). The three kinds of Bt strains $(5 \mu \mathrm{l}$ aliquot) was inoculated onto the PDA plate simultaneously with $P$. ostreatus (a) and P. geesteranus (b) (5 mm PDA discs with mycelia), then incubated in the dark for one week at $25 \pm 1^{\circ} \mathrm{C}$

(Fig. 1). After $72 \mathrm{~h}$, the corrected mortality of B. difformis larvae treated with all bacterial strains was above $50 \%$ except for strain 214-4. Strains JW-1 and 69-3 showed the highest insecticidal activity, and the corrected mortality was $91.96 \pm 3.49 \%$ and $86.21 \pm 7.26 \%$, respectively. After treatment with $\mathrm{Bt}$ for $72 \mathrm{~h}$, most larvae became darkened or started to disintegrate.

Strains JW-1 and 69-3 were tested for their antifungal activity against hyphae of $P$. ostreatus and $P$. geesteranus. The hyphae of the two fungi grew normally on the plates without showing inhibition by the bacteria. Therefore, we identified that the three Bt strains (JW-1, 69-3, Bti) did not inhibit mycelial growth (Fig. 2). Based on the results from the insecticidal and antifungal activity assays, the strain JW-1 was selected as the candidate strain for further research.

\section{Amplification of 16s rRNA and cyt2 genes}

The nearly full-length 16S rRNA gene sequence (1397 bp) of strain JW-1 shared highest homologous to Bacillus species archived in GenBank. The phylogenetic tree based on 16S rRNA gene showed that strain JW-1 was clustered together with $B$. thuringiensis (Fig. 3).

A 792 bp fragment was obtained from PCR amplification of the cyt2 gene from the total DNA of Bt strain JW-1 (Fig. 4a). The Cyt2 toxin sequence (GenBank accession no. QGM12370.1) exhibited $99 \%$ identity to the reported $\mathrm{Cyt} 2 \mathrm{Ba}$ toxin, confirming that this protein is a member of Cyt2Ba in the Cyt2 family (Fig. 5).

\section{Construction of Expression Vector}

The entire cyt2Ba (792 bp) gene was inserted into pMALc $5 \mathrm{x}$ by seamless cloning. PvuI was used for double enzyme digestion, confirming the full-length of pCYT-2 construct. The result of digestion was $2.4 \mathrm{~kb}(0.8 \mathrm{~kb} c y t 2 B a$ and $1.6 \mathrm{~kb}$ located at vector) and $4.0 \mathrm{~kb}$ vector (Fig. $4 \mathrm{~b}$ ).

\section{Induced Expression}

Escherichia coli Arctic culture (pCYT-2) was incubated with IPTG in LB medium. The toxin Cyt2Ba (30 kDa) was expressed as a fusion protein with a $40 \mathrm{kDa}$ maltose-binding protein (MBP) tag. The $70 \mathrm{kDa}$ recombinant product was visualized in SDS-PAGE, which validated the expression of Cyt2Ba toxin (Fig. 6a). Due to the protein structure, the protein appeared to be smaller than the calculated molecular weight. The results of SDS-PAGE indicated that Cyt2 was mainly present in the supernatant and expressed in soluble form, which could be directly purified by affinity chromatography.

\section{Purification of the Fusion Protein and Western Blot Verification}

After the fusion protein was purified by Ni column affinity chromatography, the initial bacterial homogenate, effluent, and eluate were separately subjected to $12 \%$ SDS-PAGE analysis. The result revealed that a relatively pure target protein fraction was obtained in the eluted fractions (Fig. 6b). After the purified protein was subjected to Western blotting (Fig. 7), the fusion protein was solubilized on the Western blot.

\section{Insecticidal Activity Assay of Cyt2Ba Toxin}

Bioassays were performed against the third instar larvae of $B$. difformis. After $72 \mathrm{~h}$ of treatment, the mortality caused by different doses of Cyt2Ba toxin showed a linear 


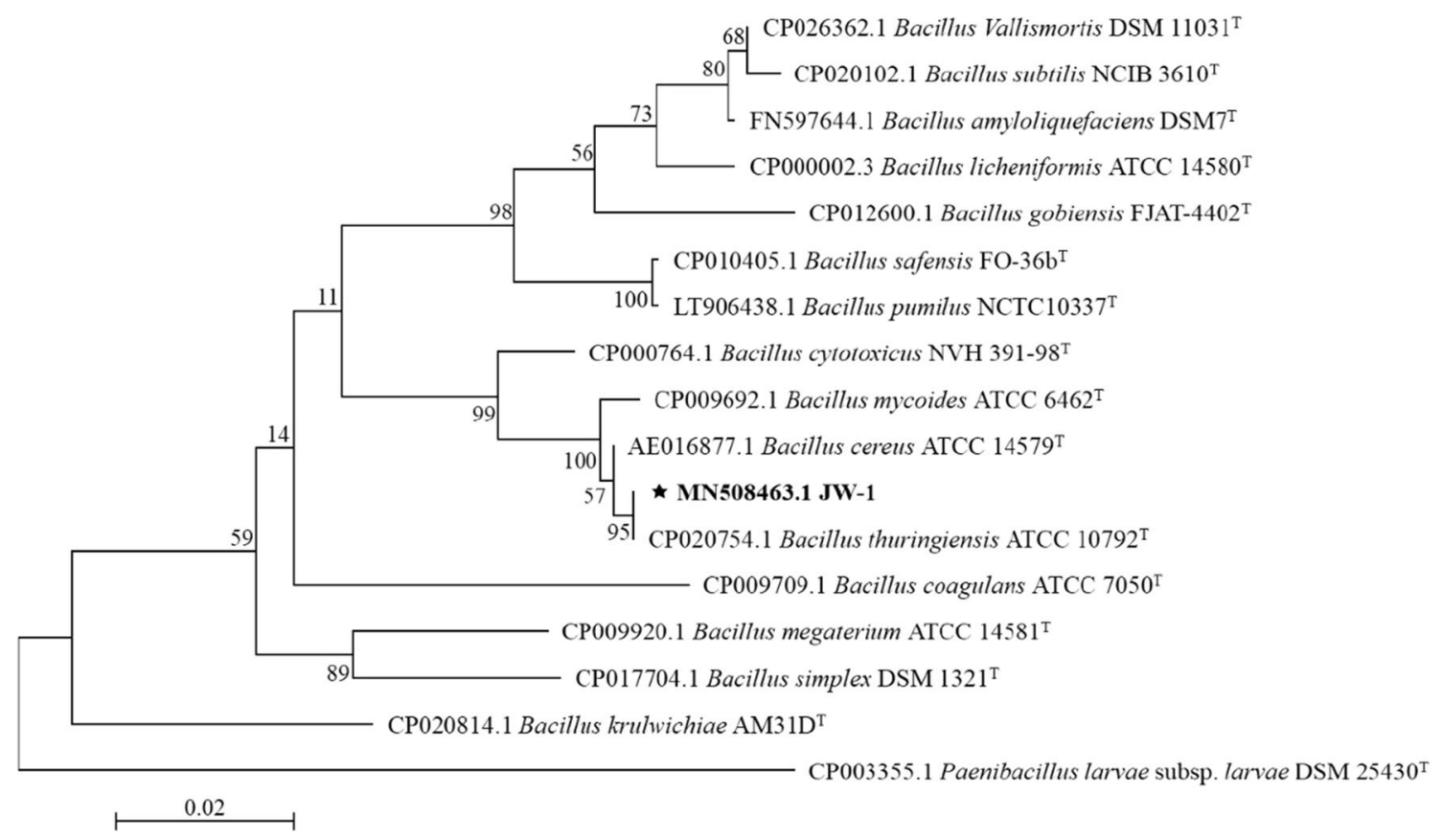

Fig. 3 Phylogenetic tree based on 16S rRNA gene sequences. The dendrograms were generated using the maximum likelihood method and gene distances were calculated using the Jukes-Cantor model

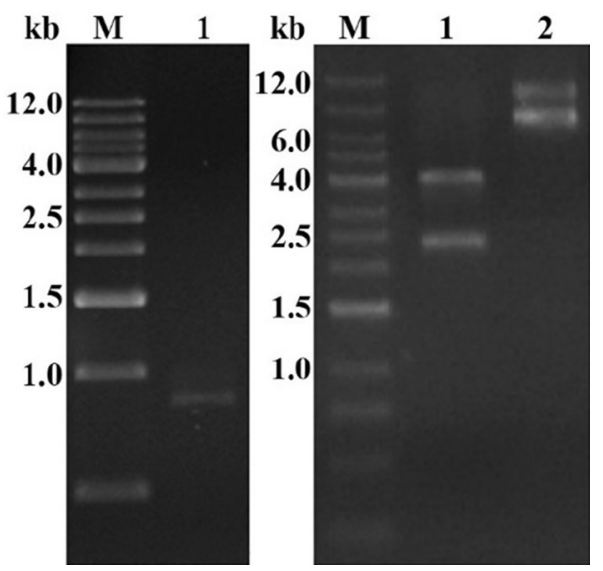

Fig. 4 The electrophoresis result of $c y t 2$ and the verification of pCYT-2. a PCR confirmation of full-length cyt2 gene around $0.8 \mathrm{~kb}$ in the JW-1 (lane 1), the primers JW-2F and JW-2R were used to amplify the cyt2 gene. b pCYT-2 plasmid was digested with $P v u I$ around $2.4 \mathrm{~kb}$ and $4.0 \mathrm{~kb}$ (lane 1), the pCYT-2 plasmid around $6.4 \mathrm{~kb}$ (lane 2)

relationship between the log dose and probe mortality. The regression equation of Cyt2Ba toxin was $y=4.49+1.45 x$ ( $x$ means the logarithm value of concentration; $y$ means the probability value of mortality). The $\mathrm{LC}_{50}$ value was $2.25 \mathrm{ng} / \mathrm{mL}$, where $95 \%$ fiducial limit for $\mathrm{LC}_{50}$ was between $1.44-3.50 \mathrm{ng} / \mathrm{mL}$ and the $R$ value was 0.9433 .

\section{Discussion}

In China, the mushroom cultivation scales range from technologically assisted industrialized production to conventional field production. Because of the short reproduction cycle and the high resistance developed to pesticides, $B$. difformis damages are more severe in simple mushroom cultivation settings. Heat stress and some biological control microorganisms, such as Beauveria bassiana and entomopathogenic nematodes (EPNs), showed the control efficacies against $B$. difformis in soil or spawned mushroom compost [37-39]. However, these methods are not effective for controlling $B$. difformis in simple mushroom cultivation in China, because of the difficulties in adequate control of temperature, potting media, and application dose [40]. In contrary Bt strains have already been used in production of mushrooms to control $B$. difformis and are readily accessible to growers due to its broad applicability.

$\mathrm{Bt}$ is an effective agent to control mosquitoes due to production of multiple toxins with different modes of action [41]. Cyt toxins in Bt synergize with the toxic effect of Cry toxins. Cyt toxins have insecticidal activity and function as a receptor to synergize the Cry11 toxicity $[42,43]$. Besides, at least two Cyt toxins are present in the Bt strains to control the Dipteran insects, such as B. thuringiensis subsp. israelensis and subsp. morrisoni [19].

In this study, the strain JW-1, as a member of B. thuringiensis, showed the obvious insecticidal activity against B. difformis larvae and did not affect the hyphal growth of 
Fig. 5 Phylogenetic tree based on Cyt 2 toxin sequences. The gene distances were calculated using the Jones-Taylor-Thornton (JTT) model and dendrograms were generated using the maximum likelihood method. Initial tree for the heuristic search were obtained automatically by applying Neighbor Joining

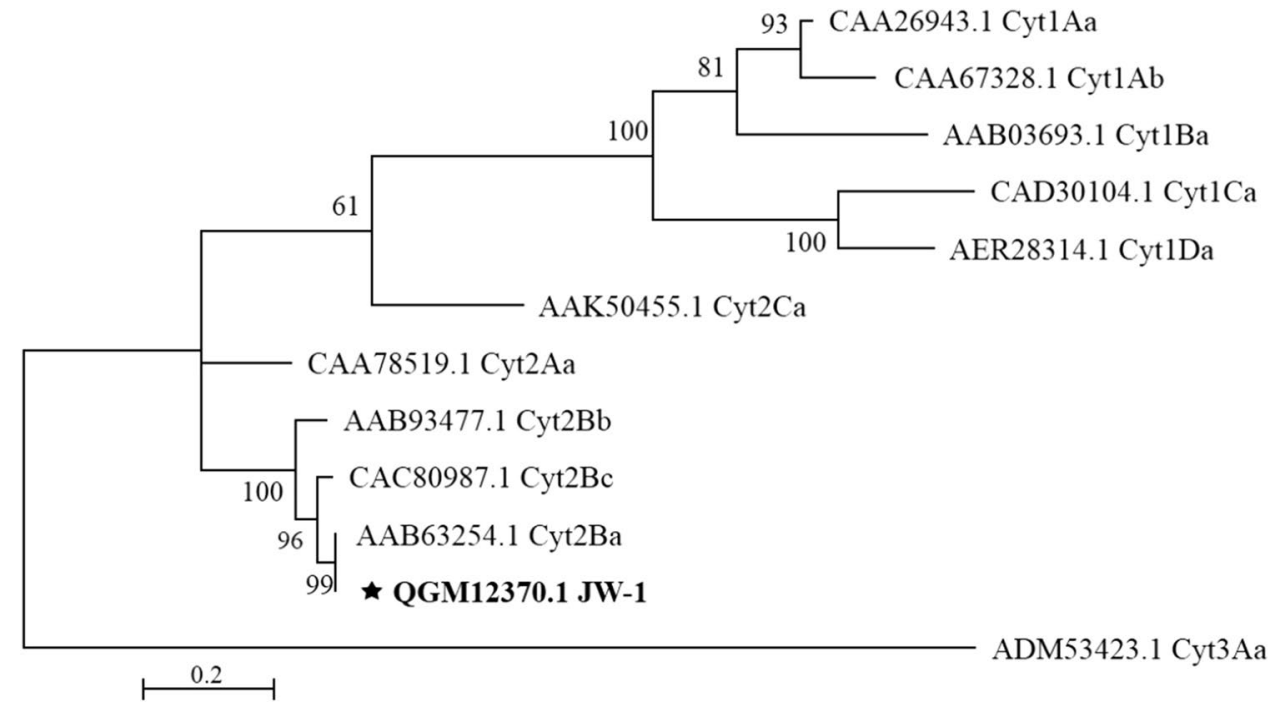

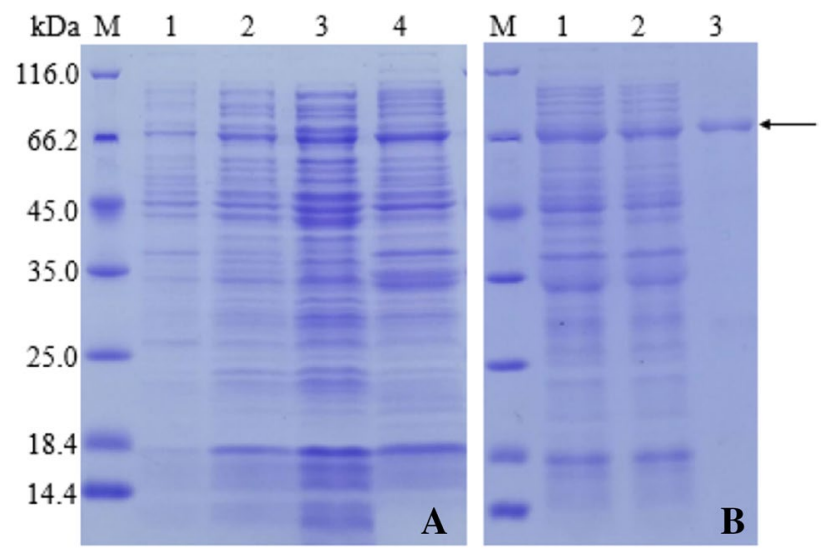

Fig. 6 SDS-PAGE analysis of expression (a) and fusion protein purification (b). a Protein expression before induction (lane 1), protein expression after induction (lane 2), the supernatant of induced fragmentation (lane 3), precipitation of induced fragmentation (lane 4). b Sample of pulverization (lane 1), effluent sample (lane 2), elution sample (lane 3)

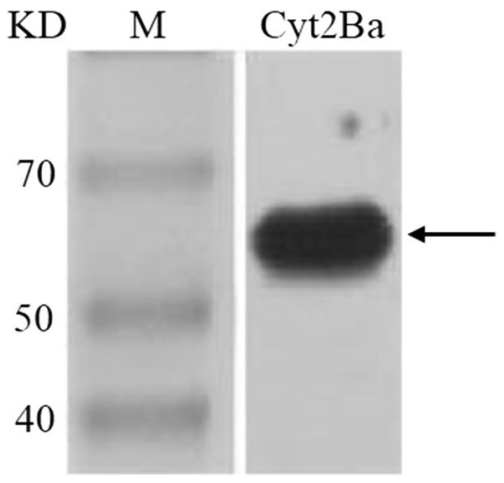

Fig. 7 Western Blot analysis of fusion protein purification mushroom. Cyt2Ba, composed of 263 amino acids, is a minor component within the complex of the crystal proteins expressed in the Bt strain [44]. The toxicity of the recombinant Cyt2Ba toxin from strain JW-1 in B. difformis larvae was confirmed by biological assay. The larvicidal activity of recombinant $\mathrm{Bt}$ toxin $\mathrm{Cyt} 2 \mathrm{Ba}$ against mosquito larvae, such as Aedes albopictus and Culex pipiens quinquefasciatus, has been reported [45], but there are few research for mushroom pest control. The results from this study showed that $B$. difformis damage in mushroom cultivation could be controlled by this $\mathrm{Bt}$ toxin as an alternative to minimize the use of chemical insecticides. Further work on the biological activity of Cyt 2 toxin and its combination with other Cyt and Cry toxins will help in our understanding of the mechanisms. This knowledge may have a significant impact on biological insect resistance-management programs.

Acknowledgements This research was supported by China Agriculture Research System (CARS20).

\section{Compliance with ethical standards}

Conflict of interest The authors declare no conflicts of interest.

Open Access This article is licensed under a Creative Commons Attribution 4.0 International License, which permits use, sharing, adaptation, distribution and reproduction in any medium or format, as long as you give appropriate credit to the original author(s) and the source, provide a link to the Creative Commons licence, and indicate if changes were made. The images or other third party material in this article are included in the article's Creative Commons licence, unless indicated otherwise in a credit line to the material. If material is not included in the article's Creative Commons licence and your intended use is not permitted by statutory regulation or exceeds the permitted use, you will need to obtain permission directly from the copyright holder. To view a copy of this licence, visit http://creativecommons.org/licenses/by/4.0/. 


\section{References}

1. Broadley A, Kauschke E, Mohrig W (2018) Black fungus gnats (Diptera: Sciaridae) found in association with cultivated plants and mushrooms in Australia, with notes on cosmopolitan pest species and biosecurity interceptions. Zootaxa 415(2):201-242. https://doi.org/10.11646/zootaxa.4415.2.1

2. Ludwig SW, Oetting RD (2001) Evaluation of medium treatments for management of Frankliniella occidentalis (Thripidae: Thysanoptera) and Bradysia coprophila (Diptera: Sciaridae). Pest Manag Sci 57(12):1114-1118. https://doi.org/10.1002/ps.404

3. San-Blas E, Luzardo M, Larreal J, Portillo E, Bastidas B (2017) Biological control of the fungus gnats Bradysia difformis (Diptera, Mycetophilidae) in mushrooms with Heterorhabditis amazonensis in tropical conditions. Sci Hortic 216:120-125. https://doi. org/10.1016/j.scienta.2017.01.003

4. Zhang P, He M, Wei Y, ZhaoY MuW, Liu F (2016) Comparative soil distribution and dissipation of phoxim and thiamethoxam and their efficacy in controlling Bradysia odoriphaga Yang and Zhang in Chinese chive ecosystems. Crop Protect 90:1-8. https://doi. org/10.1016/j.cropro.2016.07.028

5. Shamshad A (2010) The development of integrated pest management for the control of mushroom sciarid flies, Lycoriella ingenua (Dufour) and Bradysia ocellaris (Comstock), in cultivated mushrooms. Pest Manag Sci 66(10):1063-1074. https://doi. org/10.1002/ps.1987

6. Shamshad A, Clift AD, Mansfield S (2008) Toxicity of six commercially formulated insecticides and biopesticides to third instar larvae of mushroom sciarid, Lycoriella ingenua Dufour (Diptera: Sciaridae), in New South Wales, Australia. Austral Entomol 47(3):256-260. https://doi.org/10.1111/j.1440-6055.2008.00653.x

7. Cloyd RA, Dickinson A (2006) Effect of Bacillus thuringiensis subsp. israelensis and neonicotinoid insecticides on the fungus gnat Bradysia sp. nr coprophila (Lintner) (Diptera: Sciaridae). Pest Manag Sci 62(2):171-177. https://doi.org/10.1002/ps.1143

8. Long SJ, Richardson PN, Willmott DM, Edmondson RN (2000) Infectivity of entomopathogenic nematodes (Steinernematidae, Heterorhabditidae) to mushroom phorid fly (Megaselia halterata) larvae. Nematology 2(4):451-459. https://doi.org/10.1163/15685 4100509312

9. Jouzani GS, Valijanian E, Sharafi R (2017) Bacillus thuringiensis: a successful insecticide with new environmental features and tidings. Appl Microbiol Biot 101(7):2691-2711. https://doi. org/10.1007/s00253-017-8175-y

10. Sauka DH, Cozzi JG, Benintende GB (2005) Screening of cry2 genes in Bacillus thuringiensis isolates from Argentina. Antonie Van Leeuwenhoek 88(2):163-165. https://doi.org/10.1007/s1048 2-005-3368-2

11. Peng Q, Yu Q, Song F (2019) Expression of cry genes in Bacillus thuringiensis biotechnology. Appl Microbiol Biot 103(4):1161711626. https://doi.org/10.1007/s00253-018-9552-x

12. Frankenhuyzen VK (2013) Cross-order and cross-phylum activity of Bacillus thuringiensis pesticidal proteins. J Invertebr Pathol 114(1):76-85. https://doi.org/10.1016/j.jip.2013.05.010

13. Kaur S (2000) Molecular approaches towards development of novel Bacillus thuringiensis biopesticides. World J Microb Biot 16:781-793. https://doi.org/10.1023/A:1008931207374

14. Reyaz AL, Arulselvi PI (2016) Cloning, characterization and expression of a novel haplotype cry $2 \mathrm{~A}$-type gene from Bacillus thuringiensis strain SWK1, native to Himalayan valley Kashmir. J Invertebr Pathol 136:1-6. https://doi.org/10.1016/j. jip.2016.02.005

15. Hofte H, Whiteley HR (1989) Insecticidal crystal proteins of Bacillus thuringiensis. Microbiol Rev 53(2):242-255
16. Osman GEH, Already R, Assaeedi ASA, Organji SR, El-Ghareeb D, Abulreesh HH, Althubiani AS (2015) Bioinsecticide Bacillus thuringiensis a comprehensive review. Egypt J Biol Pest Control 25(1):271-288

17. Cantón PE, Reyes EZ, De Escudero IR, Bravo A, Soberon M (2011) Binding of Bacillus thuringiensis subsp. israelensis Cry4Ba to Cyt1Aa has an important role in synergism. Peptides 32(3):595-600. https://doi.org/10.1016/j.peptides.2010.06.005

18. Khasdan V, Ben-Dov E, Manasherob R, Boussiba S, Zaritsky A (2001) Toxicity and synergism in transgenic Escherichia coli expressing four genes from Bacillus thuringiensis subsp. israelensis. Environ Microbiol 3(12):798-806. https://doi.org/10.104 6/j.1462-2920.2001.00253.x

19. Soberón M, López-Díaz JA, Bravo A (2013) Cyt toxins produced by Bacillus thuringiensis: a protein fold conserved in several pathogenic microorganisms. Peptides 41:87-93. https ://doi.org/10.1016/j.peptides.2012.05.023

20. Ben-Dov E (2014) Bacillus thuringiensis subsp. israelensis and its dipteran-specific toxins. Toxins 6(4):1222-1243. https://doi. org/10.3390/toxins6041222

21. Palma L, Munoz D, Berry C, Murillo J, Caballero P (2014) Bacillus thuringiensis toxins: an overview of their biocidal activity. Toxins 6(12):3296-3325. https://doi.org/10.3390/toxin s6123296

22. Koni PA, Ellar DJ (1993) Cloning and characterization of a novel Bacillus thuringiensis cytolytic delta-endotoxin. J Mol Biol 229(2):327. https://doi.org/10.1006/jmbi.1993.1037

23. Yu J, Xu W, Zeng S, Zhang XQ, Liu JY, Xie RY, Pang Y (2002) Cloning and expression of $c y t 2 B a 7$ gene from a soil-isolated Bacillus thuringiensis. Curr Microbiol 45(5):309-314. https:// doi.org/10.1007/s00284-002-3757-y

24. Nisnevitch M, Cohen S, Ben-Dov E, Zaritsky A, Sofer Y, Cahan R (2006) Cyt2Ba of Bacillus thuringiensis israelensis: activation by putative endogenous protease. Biochem Biophys Res 344(1):99105. https://doi.org/10.1016/j.bbrc.2006.03.134

25. Wu Y, Gao M, Dai S, Yi D, Fan HY (2008) Investigation of the cyt gene in Bacillus thuringiensis and the biological activities of Bt isolates from the soil of China. Biol Control 47(3):335-339. https://doi.org/10.1016/j.biocontrol.2008.08.020

26. Wirth MC, Delecluse A, Walton WE (2001) Cyt1Ab1 and Cyt2Ba1 from Bacillus thuringiensis subsp. medellin and $B$. thuringiensis subsp. israelensis synergize Bacillus sphaericus against Aedes aegypti and resistant Culex quinquefasciatus (Diptera: Culicidae). Appl Environ Microb 67(7):3280-3284. https:// doi.org/10.1128/Aem.67.7.3280-3284.2001

27. Wang FF, Qu SX, Lin JS, Li HP, Hou LJ, Jiang N, Luo X, Ma L, Han JC (2019) Screening of Bacillus thuringiensis and identification of insecticidal crystal protein gene against Bradysia difformis in mushroom cultivation. J Zhejiang Univ 45(2):189-195. https:// doi.org/10.3785/j.issn.1008-9209.2018.08.141

28. Finney D (1971) Probit Analysis. Cambridge University Press, Cambridge, pp 50-80

29. Ma L, Wang XQ, Deng P, Baird SM, Liu YZ, Qu SX, Lu S-E (2017) The pafR gene is required for antifungal activity of strain MS82 against Mycogone perniciosa. Adv Microbiol 7:217-230. https://doi.org/10.4236/aim.2017.74018

30. Chen Y, Gao H, Zhang Y, Deng M, Wu Z, Zhu L, Duan Q, Xu B, Liang C, Yue Z, Xiao X (2012) Analysis of the bacterial diversity existing on animal hide and wool: development of a preliminary PCR-restriction fragment length polymorphism fingerprint database for identifying isolates. J AOAC Int 95(6):1750-1754. https ://doi.org/10.5740/jaoacint.11-482

31. Lalitha S (2000) Primer Premier 5. Biotech Softw Internet Rep 1(6):270-272. https://doi.org/10.1089/152791600459894

32. Tamura K, Stecher G, Peterson D, Filipski A, Kumar S (2013) MEGA6: molecular evolutionary genetics analysis version 6.0. 
Mol Biol Evol 30:2725-2729. https://doi.org/10.1093/molbev/ mst197

33. Felsenstein J (1985) Confidence limits on phylogenies: an approach using the bootstrap. Evolution 39:783-791. https://doi. org/10.1111/j.1558-5646.1985.tb00420.x

34. Jin X, Yao JM, Fan HL, Che YC, Pan JR, Zhang LL, Pan XH, Gelbič I, Huang TP, Guan X (2019) Heterologous expression and purification of $B t \mathrm{CspB}$, a novel cold-shock protein-like bacteriocin from Bacillus thuringiensis BRC-ZYR2. World J Microbiol Biotechnol 35:23. https://doi.org/10.1007/s11274-019-2595-Z

35. Delécluse A, Charles JF, Klier A, Rapoport A (1991) Deletion by in vivo recombination shows that the 28-kilodalton cytolytic polypeptide from Bacillus thuringiensis subsp. israelensis is not essential for mosquitocidal activity. J Bacteriol 173(11):33743381. https://doi.org/10.1128/jb.173.11.3374-3381.1991

36. Yun DK, Lee J, Keum YS (2013) Finasteride increases the expression of hemoxygenase-1 (HO-1) and NF-E2-related factor-2 (Nrf2) proteins in PC-3 cells: implication of finasteride-mediated high-grade prostate tumor occurrence. Biomol Ther 21(1):49-53. https://doi.org/10.4062/biomolther.2012.080

37. Andreadis SS, Cloonan KR, Bellicanta GS, Paley K, Pecchia J, Jenkins NE (2016) Efficacy of Beauveria bassiana formulations against the fungus gnat Lycoriella ingenua. Biol Control 103:165171. https://doi.org/10.1016/j.biocontrol.2016.09.003

38. Katumanyane A, Ferreira T, Malan AP (2018) Greenhouse application of Steinernema yirgalemense to control fungus gnats, Bradysia impatiens. Biocontrol 63:729-738. https://doi. org/10.1007/s10526-018-9895-3

39. Zhu GD, Yin L, Ming X, Zhao HP, Xia NN, Wang XH (2018) Effects of high-temperature stress and heat shock on two root maggots, Bradysia odoriphaga and Bradysia difformis (Diptera: Sciaridae). J Asia-Pac Entomol 21(1):106-114. https://doi. org/10.1016/j.aspen.2017.11.001

40. dos Santos LK, Soares-da-Silva J, da Silva MC, Tadei WP, Polanczyk RA, Pinheiro VCS (2018) Isolation and molecular characterization of Bacillus thuringiensis found in soils of the Cerrado region of Brazil, and their toxicity to Aedes aegypti larvae. Rev Bras Entomol 62(1):5-12. https://doi.org/10.1016/j. rbe.2017.11.004

41. Regis L, Silva SBD, Melosantos MAV (2000) The use of bacterial larvicides in mosquito and black fly control programmes in Brazil. Mem Inst Oswaldo Cruz 95(suppl. 1):207-210. https://doi. org/10.1590/s0074-02762000000700035

42. Pérez C, Fernandez LE, Sun J, Folch JL, Gill SS, Soberón M, Bravo A (2005) Bacillus thuringiensis subsp. israelensis Cyt1Aa synergizes Cry11Aa toxin by functioning as a membrane-bound receptor. PNAS 102(51):18303-18308. https://doi.org/10.1073/ pnas.0505494102

43. Vidal-Quist JC, Castañera P, González-Cabrera J (2010) Cyt1Aa protein from Bacillus thuringiensis (Berliner) serovar israelensis is active against the Mediterranean fruit fly, Ceratitis capitata (Wiedemann). Pest Manag Sci 66(9):949-955. https://doi. org/10.1002/ps.1965

44. Cohen S, Dym O, Albeck S, Ben-Dov E, Cahan R, Firer M, Zaritsky A (2008) High-resolution crystal structure of activated Cyt2Ba monomer from Bacillus thuringiensis subsp. Israelensis. J Mol Biol 380:820-827. https://doi.org/10.1016/j.jmb.2008.05.010

45. Deng S, Deng M, Chen J, Zheng L, Peng H (2017) Larvicidal activity of recombinant Escherichia coli expressing scorpion neurotoxin AaIT or B.t.i toxin Cyt2Ba against mosquito larvae and formulations for enhancing the effects. $J$ South Med Univ 37(6):750-754. https://doi.org/10.3969/j. issn.1673-4254.2017.06.06

Publisher's Note Springer Nature remains neutral with regard to jurisdictional claims in published maps and institutional affiliations. 